IZA DP No. 651

\title{
Social Evolution, Corporate Culture, and Exploitation
}

\author{
Ekkehart Schlicht
}

November 2002 


\title{
Social Evolution, Corporate Culture, and Exploitation
}

\author{
Ekkehart Schlicht \\ University of Munich \\ and IZA Bonn
}

\section{Discussion Paper No. 651 \\ November 2002}

\author{
IZA \\ P.O. Box 7240 \\ D-53072 Bonn \\ Germany \\ Tel.: +49-228-3894-0 \\ Fax: +49-228-3894-210 \\ Email: iza@iza.org
}

This Discussion Paper is issued within the framework of IZA's research area Welfare State and Labor Market. Any opinions expressed here are those of the author(s) and not those of the institute. Research disseminated by IZA may include views on policy, but the institute itself takes no institutional policy positions.

The Institute for the Study of Labor (IZA) in Bonn is a local and virtual international research center and a place of communication between science, politics and business. IZA is an independent, nonprofit limited liability company (Gesellschaft mit beschränkter Haftung) supported by the Deutsche Post AG. The center is associated with the University of Bonn and offers a stimulating research environment through its research networks, research support, and visitors and doctoral programs. IZA engages in (i) original and internationally competitive research in all fields of labor economics, (ii) development of policy concepts, and (iii) dissemination of research results and concepts to the interested public. The current research program deals with (1) mobility and flexibility of labor, (2) internationalization of labor markets, (3) welfare state and labor market, (4) labor markets in transition countries, (5) the future of labor, (6) evaluation of labor market policies and projects and (7) general labor economics.

IZA Discussion Papers often represent preliminary work and are circulated to encourage discussion. Citation of such a paper should account for its provisional character. A revised version may be available on the IZA website (www.iza.org) or directly from the author. 
IZA Discussion Paper No. 651

November 2002

\title{
ABSTRACT
}

\section{Social Evolution, Corporate Culture, and Exploitation}

It has been claimed that the market fosters selfishness and thereby undermines the moral basis of society. This thesis has been developed with an emphasis on market exchange. Everyday life is, however, predominantly shaped by interactions in the workplace rather than by shopping behaviour. This essay places emphasis on firm organisation, rather than market interaction, in moulding cultural traits. The argument starts with the observation that workers may perceive the employment relationship in two different ways, with different behavioural consequences. The first is the conventional incentive view. The other is the social exchange view. Implementing the social exchange perspective may be profitable for firms which organize complex tasks. This requires an appropriate corporate culture, governed by reciprocity, fairness and commitment. Such a culture can be viewed as a refined form of exploitation, however, as it involves creating an atmosphere of mutuality for profit. I shall argue against this thesis that the same attribution mechanisms which render corporate culture an effective management instrument shape the self-perception of management and engender true, rather than faked, social exchange. The market shapes firm organizations which foster mutualism rather than selfishness.

JEL Classification: $\quad$ A13, A14, B52, D21, D23, L14, L22

Keywords: theory of the firm, corporate culture, organizational citizenship, reciprocity

\author{
Ekkehart Schlicht \\ Institutional Economics Group \\ (Seminar für Theorie und Politik der Einkommensverteilung) \\ Department of Economics \\ University of Munich \\ Schackstr. 4 \\ 80539 Munich \\ Germany \\ Tel.: +49 (89) 2180-2219 \\ Fax: +49 (89) 2180-3900 \\ Email: ekkehart.schlicht@Irz.uni-muenchen.de
}


.. the moral basis of capitalism will be seen as being constantly depleted and replenished at the same time.

AlBeRT HiRSCHMAN (1982:1483)

\section{$1 \quad$ Introduction}

The competitive market process allocates resources and shapes institutions. At the same time, and perhaps more importantly, it moulds cultural traits and attitudes which prevail in society. The theory of social evolution proposes that attitudes which entail successful behaviours will be adopted and maintained more readily than less successful variants, and will therefore spread and attain dominance over time. For example, a code of honour may be thought to emerge under feudalism, but will be eroded in a market economy. ${ }^{1}$

Previous writers have suggested that the expansion of the market restrains the passions and encourages rational goal-oriented behaviour; it weakens social bonds and strengthens self-reliance. ${ }^{2}$ Some see this process as a process of civilisation, where atavistic tribal and feudal mentalities are replaced by more rational and individualistic attitudes; others portray it as self-destructive because many socially desirable traits which enhance social interaction and render the market system workable - like trust, reciprocity, and social responsiveness - will be eroded in the course of time, and the moral and intellectual foundations of the market process will be destroyed by unhampered competition and increased affluence. ${ }^{3}$

${ }^{1}$ HiRSCHMAN (1977)

${ }^{2}$ Surveys are provided by HIRSCHMAN (1982) and BOWLES (1998).

${ }^{3}$ KARL POLANYI (1944), SCHUMPETER (1943) 
These arguments have been developed with an emphasis on price competition in markets as the dominant mode of social interaction. ${ }^{4}$ However, most interaction - even in modern market economies - takes place within firms and families, that is, within institutions and organizations that do not rely on the price mechanism for purposes of internal co-ordination. People spend most of their time in such organizations, and a lesser time doing shopping.

In the following I will concentrate on the impact of firm organization on the evolution of cultural traits. Firm organization is, of course, an integral part of the market process. Hence the process of enculturation envisaged here concerns the indirect, rather than direct, effects of the market process on attitude formation, as it works through firm organization. These indirect effects can be expected to be of greater significance than the direct effects, because social interaction within firms seems to be more important than market interaction. As will be shown, the indirect effects on attitudes and behavior are less destructive and morally more appealing than the direct effects of market competition.

The chain of causality envisaged here is as follows: Market competition induces firms to adopt efficient forms of internal organization. This internal organization shapes attitudes and behavioral inclinations of the employees. Market success determines which organizational structure is chosen. Organizational forms which generate productivity-enhancing attitudes will outcompete others, and market forces will ultimately encourage corresponding traits. If co-operation is of great productive value, for instance, the market will engender, via its

\footnotetext{
${ }^{4}$ In his comprehensive account, BOWLES $(1998,78)$ commences with observing that production may be organized in various ways, based, e.g., on fiat, authority, age, gender, kinship, gift, theft, bargaining or markets. Each mode of organization will induce a characteristic pattern of interaction on the people who make up a society. However, his subsequent analysis addresses almost exclusively the impact of markets on cultural traits, though he emphasizes the importance of business morality for incomplete contracting. That issue may be seen as the main concern of the present paper.
} 
impact on firm organization, co-operative attitudes. Under such circumstances it would be wrong to insist that the market encourages selfishness. Such a statement would only apply to the relatively unimportant direct effects of market interaction and would neglect the all-important indirect effects which work in the opposite direction.

In more familiar language, the argument can be rephrased in terms of the working of incentives. It has been emphasized recently that the impact of economic incentives is not only a matter of the incentives themselves, but also of the worker's responsiveness to those incentives. ${ }^{5}$ The position taken here - and shared by many industrial psychologists and compensation theorists - is that the implementation of compensation policies provides incentives and at the same time shapes the workers' responsiveness to these incentives along with their overall work attitude. Applying economic incentives without accounting for the motivational effect could entail ruinous consequences.

The traditional principal-agent framework neglects the motivational aspects of incentives i.e., their impact on motivation and work attitudes. As a consequence, many empirical features of actual compensation systems must remain enigmatic. Modern compensation theory with its emphasis on "corporate culture" and "consistency" of the firms' policies places emphasis on the effect of organization on work attitudes, and it is this line of research which is taken up here. ${ }^{6}$

\section{Organizational Citizenship and Corporate Culture}

Recent discussion in organization theory has emphasized the importance of organizational citizenship behavior. ${ }^{7}$ Organizational citizenship behavior refers to activities which foster the firm's goals but are not directly job related and not rewarded. Typical instances are: helping other workers with their tasks, voicing concerns, defending the firm's

\footnotetext{
${ }^{5}$ BOWLeS, GinTIS \& OSBORNE (2001).

${ }^{6}$ Milkovich\&Newman (1999).

${ }^{7}$ ORGAN (1988).
} 
policies or making favorable statements in public. It has been urged that perceived fairness encourages organizational citizenship behavior, while unfairness undermines it. ${ }^{8}$ In a more general way, literature on "corporate culture" emphasizes the influence of "atmosphere" and "attitudinal inseparability" on performance. ${ }^{9}$

"Atmosphere" and "corporate culture" are holistic concepts. They refer to the ways in which an entire organization is perceived. The effect of these holistic influences is well illustrated by a recent study on performance pay. ${ }^{10}$ According to standard theory, an increase in performance pay will lead to an increase in the rewarded activity, and to a corresponding decrease in other activities. ${ }^{11}$ Earlier studies of organizational citizenship behavior have conjectured that performance pay reduces organizational citizenship behavior and have for this reason been skeptical about economic incentives. The study by DECKOP, MANGEL and CIRCA (1999) finds that the effect of performance pay on corporate citizenship behavior may in some cases actually turn out to be positive, rather than negative,. This occurs if the worker's attachment to the firm is initially strong. In this case, increased performance pay may actually increase organizational citizenship behavior.

The interpretation given by the authors is that a worker with strong loyalty to his firm will view a performance pay component as a sharing arrangement. Guided by reciprocity, he will reciprocate this gift in all dimensions, including extra job corporate citizenship activity. This explains the positive association between performance pay and corporate citizenship behavior. ${ }^{12}$

\footnotetext{
${ }^{8}$ MOORMAN (1991)

9 "Atmosphere" and "attitudinal interactions" viz. inseparability refer to WILLIAMSON (1975: 37-39).

${ }^{10}$ DeCKOP, MANGel \& CirCa (1999).

11 Recent experimental evidence for this effect is provided in FEHR\&GÄCHTER (2000) and GÄCHTER\&FALK (forthcoming)

12 Sociologists and anthropologists speak of "generalized exchange" (echange généralisé - LÉVI-STRAUSS 1967). The term “reciprocity” has been initially introduced into economic anthropology in this sense (KARL POLANYI 1944: 47; 1977: ch. 3)).
} 
The standard (negative) reaction can also be observed. It comes about when workers perceive performance pay as an incentive and behave accordingly. This can be expected if the workers are less attached to the firm and view the employment contract as an exchange contract, governed by quid-pro-quo considerations. ${ }^{13}$

The crucial issue is: What makes the workers perceive the employment relationship as a social exchange rather than a market exchange? This is obviously a question of the interpretation given to the employment relationship.

I propose to answer this question in terms of attribution theory. ${ }^{14}$ The worker is faced with a multitude of organizational features which he perceives while working in the firm. He will try to make sense of what he sees and will attribute intentions and causes to the various regulations he observes, just as he would attribute intentions to another person interacting with him, in spite the fact that the "firm" is not an individual. He tries to develop a coherent picture of "the firm's" actions and motives. This is the corporate culture as perceived by the worker. The term "corporate culture" will be used in the sense of a shared coherent and unified perception of the firm's dealings and policies. ${ }^{15}$

If the worker observes that fairness principles play a prominent role in the dealings of the firm with its constituents, stakeholders, and customers, he will then conclude that considerations of fairness are an important feature of corporate culture. This interpretation will apply also to the employment contract, which will then be viewed as ruled by

\footnotetext{
13 The dichotomy "social exchange" and "quid-pro-quo exchange" underlying the study by DECKOP, MANGEL \& CIRCA (1999) is extremely simplifying but useful for the present purpose; see SCHLICHT $(1998$, ch. 13) on the interactions of different modes of control. See HOLLÄNDER (1990) for a theory of social exchange.

${ }^{14}$ See ZimbardO\&LeipPE (1991: ch. 3) for an introduction. VAN RAAIJ (1985) has advocated economic applications of attribution theory. In the following, I subsume a set of psychological theories and disregard many fine points in order to provide a starting point for the subsequent argument.
} 
norms, rather than by scarcity, and will entail the interpretation as a social exchange. Such a perception will be strengthened by other observations, possibly quite unrelated to compensation. The firm may donate to worthy causes, for instance. As this behavior cannot be interpreted in terms of greed, the terms of the labor contract are less likely be interpreted as brought about by greed either.

On the other hand, the social exchange interpretation will be weakened if the firm behaves profit-oriented rather than norm-guided in some of its dealings, and without any valid excuse. If the firm requires the sales people to work with customers in a strictly profit-oriented and even in a deceitful way, its corporate culture will be perceived as strongly concerned with profits. This strengthens the idea that the firm could deal with the workers in the same manner. They will then be less inclined to see the employment relationship as a social exchange.

The attribution mechanism sketched above may contribute towards elucidating the holistic nature of corporate culture and the attitudinal inseparability mentioned by WILLIAMSON, but it has not yet accounted for the influence of corporate culture on behavior.

One line of reasoning would run in terms of reciprocity. A worker who feels that he is treated fairly and generously will be inclined to reciprocate in the same spirit. This amounts to interpreting the employment relationship as a social exchange. On the other hand, the firm may offer incentives which are directly related to the profitability of certain tasks. Such incentives will not be viewed as sharing arrangements or fair compensation, but will rather be perceived as dictated by the firm's desire to instrumentalize the worker in its pursuit of profit. The worker will reciprocate by emphasizing his own advantage. He will see

\footnotetext{
15 This conception of corporate culture is different from the concept proposed by KREPS (1990), which refers to a focal point which serves to co-ordinate expectations and action.
} 
the employment contract as a quid-pro-quo exchange. Each party will pursue its own interest and will perceive the other party as behaving alike. $^{16}$

Corporate culture moulds the workers' attitudes and behavior in another important way. Assume that the worker is faced with a corporate culture emphasizing fairness and mutuality. He will then see the employment relationship as a social exchange. Reciprocity will cause him behave in a similar way in his interactions. This will induce the self-perception that he is a person who places great emphasis on these motives. As his own actions are best interpreted in terms of co-operative attitudes, the worker will develop identity which emphasises these attitudes. ${ }^{17}$

The reverse may also happen. If the employment relationship is seen as a quid-pro-quo exchange, the worker will be induced to emphasize his personal interests, and he will develop a self-perception emphasizing these characteristics as personal behavioral traits and attitudes.

Through the mechanism of self-attribution, behavior shapes selfperception and motivation. Corporate culture moulds individual identities.

\footnotetext{
${ }^{16}$ See also the related argument by PRENDERGast and STOLE (1999) that the suppression of intra-firm pricing may be understood in terms of easing interactions based on reciprocity. Reciprocity is sometimes seen as a "universal norm', shared by all human beings (GOULDNER 1960). In contrast, SCHLICHT (1998: 115-6) proposes to view reciprocity as an instance of rule preference.

${ }^{17}$ In other words, the "fundamental attribution error" (Ross 1977) is invoked with regard to self-attribution. Recent theorizing about identity in economics (AKERLOF\&KRANTON 2000) and expressive rationality (HARTGRAVES HEAP 2001; SCHUESSLER 2000) relates directly to a desire for a coherent and clear selfinterpretation.

The psychological concept of self-attribution refers to way in which persons attribute reasons and causes to their own action. This differs from the usage of term by LANE (1991:155-180) which refers to attributing an internal locus of control to one's own action. The mechanism sketched above is developed in SCHLICHT (1998: ch. 9).
} 


\section{A Scenario of Increasing Job Idiosyncrasies}

It is easier to automate easy tasks, and more difficult to automate more demanding tasks. Nowadays the conveyor belt can be served by robots, and large segments of organizational work can be computerized. What remains is work of a largely idiosyncratic nature. As a consequence, job idiosyncrasies can be expected to become increasingly important. Previous master-servant relationships will turn into fiduciary relationships. ${ }^{18}$ In the same way, corporate citizenship behavior will become increasingly crucial as an element of a firm's performance.

Firms facing pronounced job idiosyncrasies cannot rely on commands and incentives for controlling job or extra-job performance. Rather they have to rely on intrinsic motivation. It will pay in terms of profitability to inculcate a sense of duty and responsibility in the employees, mainly because explicit monitoring and control becomes prohibitively costly under such conditions. As a consequence, firms will tend to adopt a corporate culture emphasizing mutual commitment and social exchange. Under such conditions, performance pay will be designed as flowing from overarching principles of fairness, rather than rational manipulation. ${ }^{19}$

In a scenario where social exchange becomes increasingly superior to quid-pro-quo exchange in the majority of firms, we can expect corporate cultures to emerge which emphasize commitment, fairness, and the joint pursuit of the firm's social mission. The profit motive will be presented as a goal subservient to higher ends, social exchange will be emphasized and quid-pro-quo exchange will be discounted.

18 EASTERBROOK\&FiSCHEL (1991, ch. 4)

19 The emphasis on consistency and fairness in modern compensation theory, and the discounting of instrumental aspects in the design of performance pay witnesses this tendency. Neither the determination of piece rates by time measurement nor the Halsey method of splitting cost reductions 50-50 between employers and employees can be rationalized in terms of "optimal' incentive design, see MILKOVICH\&NEWMAN (1999). 
Under conditions of increased idiosyncrasy (and somewhat paradoxically) it would be profitable to abate the profit motive in everyday dealings with workers, suppliers and clients by acting generously and respecting broader commitments. This would inculcate the attribution that the firm is a coalition of stakeholders, governed by principles of reciprocity and co-operation. ${ }^{20}$

\section{The Problem of Exploitation}

Modern compensation theorists are quite aware of these possibilities but take a rather cynical view of organizational tasks, in the sense that a good corporate climate and an atmosphere of trust and reciprocity is recommended primarily as a means for profit maximization. Such a parlance suggests that organizational measures are just instruments of exploitation. Generosity and mutual respect are to be mimicked by management for the purpose of enhancing production and inducing the workers' identification with the firm's goals, but not for reasons of fairness and mutuality, as entailed by trust and mutual respect.

Interpreted in this way (which I am about to criticize), the market would induce corporate cultures and policies fostering mutuality in cases where co-operation and trust are important. But all talk about mutuality would be delusion, as these policies are implemented for exploitation. Such exploitation is veiled by the illusion of mutuality, in contrast to

\footnotetext{
${ }^{20}$ Such policies can be implemented in firms, not across markets. This thought provides a further reason for the establishment of firms. The requirement of coherence in the firm's policies restricts, however, the scope of such firms, thereby providing an argument for the limits of integration. If certain production lines or certain types of employment are incompatible with the established corporate culture, integration of such production lines may be harmful. The established principles of compensation policy may demand, for instance, that certain jobs (janitors and drivers, for instance) be paid much above the market wage. Paying them less would destroy the perception of a corporate culture based on reciprocity. A way out would be to disintegrate these jobs and hiring the corresponding services on the market. The reverse is equally true: The German electronics giant Siemens has, for instance, disintegrated a high tech division in order to offer higher pay for the corresponding jobs without being forced to increase the pay for the other jobs correspondingly (MÜCKE 2001).
} 
classical open exploitation, but such a hidden form of exploitation may be even more repulsive morally, as it involves deceit. Organizational measures are used to brain-wash workers and to mould them according to the firm's interest.

\section{$7 \quad$ Cynicism, Generosity and Self-Attribution}

My criticism of this view is as follows. Consider an economic environment which makes it profitable to create a corporate culture with an emphasis on mutuality. There are two types of managers who will succeed in such a market: the Cynical and the Generous. Both will behave alike. The Cynical will not believe in the values emphasized in their corporate culture, but they will preach these values and encourage them in order to increase profits. The Generous believe in these values and will preach and encourage them out of conviction; and as a byproduct, they will run profitable companies, just like the Cynical do. ${ }^{21}$ There will be no selection for the Cynical and against the Generous in the market and in social evolution.

But people are not cynical or generous by nature. Rather, their character tends to be moulded by circumstance. Their identity is shaped by the way in which they interact with others. If I am a cynic but behave generously all the time for sundry reasons, I will begin to see myself as a generous person. This will, in short, be the prediction made by the theory of self-attribution. ${ }^{22}$

Applied to management, this argument would suggest that the Cynical will turn generous in the course of time if the market rewards a generous corporate culture. The implementation of such a corporate culture may initially be motivated by the search for profit. But once it is

\footnotetext{
${ }^{21}$ The example of the Shakers comes to mind: Their religious convictions made them very reliable business partners, and made them economically successful. They placed more weight on God than on profit, and this apparently generated more profits than straightforward profit maximization.

${ }^{22}$ SCHLICHT (1998: Ch. 9).
} 
successfully implemented, people will start to believe in these values even those who initially made them up on purpose.

In other words, the self-attribution argument applies not only to workers, but also to management. Seen from this perspective, market processes may foster an atmosphere of social exchange.

ADAM SMITH argued forcefully that an increased division of labor, so important for enhancing the affluence of a society, would, at the same time, entail a deplorable empoverishment of human character:

In the progress of the division of labour, the employment of the far greater part of those who live by labour, that is, of the great body of the people, comes to be confined to a few very simple operations, frequently to one or two. But the understandings of the greater part of men are necessarily formed by their ordinary employments. The man whose whole life is spent in performing a few simple operations, of which the effects are perhaps always the same, or very nearly the same, has no occasion to exert his understanding or to exercise his invention in finding out expedients for removing difficulties which never occur. He naturally loses, therefore, the habit of such exertion, and generally becomes as stupid and ignorant as it is possible for a human creature to become. The torpor of his mind renders him not only incapable of relishing or bearing a part in any rational conversation, but of conceiving any generous, noble, or tender sentiment, and consequently of forming any just judgment concerning many even of the ordinary duties of private life. ${ }^{23}$

He proposed public education as a means to counter-balance this harmful tendency. In discussing the effect of the division of labor on individual attitudes, SMITH neglects the organizational repercussions which are emphasized in this paper, but SMITH's contention can readily be extended to cover this issue. He suggests that the deepening of the 
division of labor entails a disqualification of labor. The idiosyncratic work of medieval artisan-workers is reduced to simple operations. Issues of corporate citizenship are becoming less important, and the advantages of creating an appropriate corporate culture would be much less pronounced.

The argument presented here reverses this classical position. The supposition is that that technical progress induces changes in the nature of work and work organization which will encourage social exchange. In a SMITHIan vein it could be added that the tasks left for human workers will require increasingly more intelligence and involvement in the course of technical progress - an insight emphasized by AlFRED MARSHALL a hundred years ago. ${ }^{24}$

The argument hinges on the character of technical progress. Its nature determines which development will take place - whether we will take SMITH's or MARSHALL's path. In this sense, the thesis of this paper is conjectural. If technical progress leads to the disqualification processes envisaged by SMITH, and to a necessity of introducing authority and command rather than social exchange in firms, we must expect dire consequences with regard to attitude formation. If technical progress entails, in a MARSHALLian vein, richer work environments and an increased necessity to rely on mutualism and social exchange, we can expect the more optimistic consequences emphasized in this essay.

Further, the thesis speaks neither in favor nor against market organization as such. It does not say, in any absolute sense, that the market is good or bad with respect to the development of human faculties and attitudes. An ideal planning system - whatever this may be - could be expected to foster work environments appropriate to the prevailing technologies in a very similar way. The issue about attitude

\footnotetext{
${ }^{23}$ SMITH $(1776,302-3)$.

${ }^{24}$ Marshall (1920: 208-221). Some empirical support for this view may be found in AcEmouglu (2000) .
} 
formation relates primarily to the effects and exigencies of the division of labor.

\section{Market Repercussions}

An increase in the importance of idiosyncratic work will foster corporate cultures which cope with the entailing necessities of commitment, informal co-operation and corporate citizenship. This may enhance market performance by reducing the necessity to safeguard against opportunism in market transactions and by enabling relational exchanges. The reverse is that such a development may constrain and hamper many other market processes, especially in the labor market.

Assume a business environment fostering corporate cultures which emphasize fairness requirements. This would include an emphasis on a "consistent" internal wage structure and a corresponding decoupling of wage-setting processes within firms from prevailing market conditions. ${ }^{25}$ Market clearing problems of the type emphasized by efficiency wage theories and insider-outsider theories could become endemic. ${ }^{26}$ One political answer to these developments would be to suffocate corporate cultures which emphasize fairness concerns. This would eliminate the problem but at the same time hinder the development of socially and economically productive attitudes. A better response would be to find ways for keeping the labor market functioning in an environment of cooperative corporate cultures. ${ }^{27}$ Such a policy, if feasible, would foster those socially beneficial attitudes. The position is similar to that taken by ADAM SMITH. He glorified the virtues of the division of labor and recommended policy measures to cope with the disadvantageous side effect; the present argument glorifies "nice" corporate cultures and

\footnotetext{
${ }^{25}$ This trend is reflected in wage policies advocated in modern textbooks; see MiLKOVICH\&NEWMAN (1999).

${ }^{26}$ MÜCKE (2001).

${ }^{27}$ See SCHLICHT (1995).
} 
recommends the development of remedies against the entailing market failures.

It has been maintained by many writers that capitalism breeds selfishness because selfishness succeeds in the marketplace best. The considerations about work motivation in an environment characterized by increasing job idiosyncrasies suggest a different stance. In cases where motivation, involvement and commitment are important, selfishness may be outcompeted by generosity. Under such circumstances it is profitable to implement corporate cultures which emphasise social exchange rather than selfishness. Both the workers and management will tend, in the long term, to interpret their own dealings as flowing from broader commitments. Social evolution may enhance, rather than abate, cooperative attitudes and mutualism. The argument which has been invoked to portray the future of market economies as "annihilating the human and natural substance of society" is turned upside down once the importance of the firms' internal organisation is acknowledged. ${ }^{28}$

\section{References}

Acemoglou, D. 2000, “Technical Change, Inequality, and the Labor Market”, NBER Working Paper 7800, www.nber.org/papers/w7800

AKerlof, G., and R. E. Kranton 2000, "Economics and Identity", Quarterly Journal of Economics 105(3), pages 715-753.

BOwles, S. 1998, "Endogenous Preferences: The Cultural Consequences of Markets and other Economic Institutions," Journal of Economic Literature, 36, pages 75-111.

BOwles, S., H. GINTIS, and M. OSBORNE 2001, "Incentive-Enhancing Preferences: Personality, Behavior, and Earnings”, American Economic Review 91(2), pages 155-158.

\footnotetext{
${ }^{28}$ The quotation is from POLANYI (1944: 3).
} 
Deckop, J. R., R. MAngel and C. CirCA 1999, "Getting More Than You Pay For: Organizational Citizenship and Pay-Performance Plans”, Academy of Management Journal, 42(4), pages 420-428.

EASTERBROOK, F. H. and D. R. FisCHEL 1991, The Economic Structure of Corporate Law, Cambridge, Mass.: Harvard University Press.

FEHR, E. and S. GÄCHTER 2000, "Do Incentive Contracts Crowd out Voluntary Cooperation?”, Institute of Empirical Research in Economics, University of Zurich, Working Paper No. 34.

GÄCHTER, S. and A. FALK (forthcoming), "Work Motivation, Institutions, and Performance", to appear in R. ZWICK and A. RAPOPORT (eds.), Advances in Experimental Business Research, Dordrecht: Kluwer.

Gouldner, A. W. 1960, “The Norm of Reciprocity: A Preliminary Statement”, American Sociological Review 25, pages 161-78.

Hartgreaves HeaP, S. 2001, "Expressive Rationality: Is Self-Worth Just Another Kind of Preference?”, in U. MÄKI (ed.), The Economic World View, Cambridge: Cambridge University Press 2001, pages 98-113.

Hirschman, A. O. 1977, The Passions and the Interests: Political Arguments for Capitalism Before its Triumph, Princeton: Princeton University Press.

Hirschman, A. O. 1982, "Rival Interpretations of Market Society," Journal of Economic Literature, 20, pages 1463-84.

HOlländer, H. 1990, “A Social Exchange Approach to Voluntary Cooperation”, American Economic Review, 80(3), pages 1157-1167

Kelley, H. H. 1972, “The Process of Causal Attribution”, American Psychologist, 28, pages 107-28.

KREPS, D. M. 1990, “Corporate Culture and Economic Theory,” In J. E. Alt and K. A. SHEPSLE (Eds), Perspectives on Positive Political Economy, Cambridge: Cambridge University Press, pages 90--143.

LANE, R. E. 1991, The Market Experience, Cambridge: Cambridge University Press.

LÉVI-STRAuSS, C. 1967, Les Structures Élementaires de la Parenté, $2^{\text {nd }}$ ed., Paris: Mouton. 
Marshall, A. 1920, Principles of Economics, eight edition, London: Macmillan. (First edition 1890), cited from the reset eighth edition, 1949.

MENGER, C. 1883, Untersuchungen über die Methode der Socialwissenschaften und der politischen Ökonomie insbesondere, Leipzig and Tübingen: Mohr-Siebeck (reprint).

Milkovich, G. T, and J. NewMan 1999, Compensation, 6th edition, Boston et al.: Irwin/McGraw Hill.

MoOrman, R. H 1991, „Relationship between Organizational Justice and Organizational Citizenship Behavior: Do Fairness Perceptions Influence Employeee Citizenship?”, Journal of Applied Psychology, 76(6), pages 845-855.

MüCKE, P. (2001), Unternehmensgrenzen und Arbeitsmärkte, Marburg: Metropolis.

Organ, D. W. 1988, Organizational Citizenship Behavior, Lexington: Heath.

POLANYI, K. 1944, The Great Transformation, New York: Beacon 1957.

PolanYI, K. 1977, The Livelihood of Man, ed. H. W. PEARSON, New York: Academic Press.

PRENDERGAST, C., and L. STOLE 1999, "Restricting the means of exchange within organizations", European Economic Review 43(46), pages 1007-1019

RAAIJ, F. VAN 1985, "Attribution of Causality to Economic Actions and Events”, Kyklos 38(1), pages 3-19.

Ross, L. 1977, “The Intuitive Psychologist and his Shortcomings”, in L. BERKOWITZ (ed.), Advances in Experimental and Social Psychology x, New York: Academic Press, pages 173-220.

SCHLICHT, E. 1995, “Autonomous Wage Inflation”, in: Determinanten der Lobnbildung, edited by K. GERLACH and R. SCHETTKAT, Berlin: Edition Sigma 1995, pages 187-201.

SCHLiCHT, E. 1998, On Custom in the Economy, Oxford: Clarendon.

Schumpeter, J. A. 1943, Capitalism, Socialism, and Democracy, London: George Allen and Unwin. 
Schuessler, A. A. 2000, A Logic of Expressive Choice, Princeton and London: Princeton University Press.

SMITH, A. 1776, The Wealth of Nations, edited by E. CANNAN, with a preface by G. J. STIGLER, Chicago: The University of Chicago Press 1976.

Williamson, O.E. 1975, Markets and Hierarchies. Analysis and Antitrust Implications, New York: Free Press.

Zimbardo, P. G., and M. R. LeIPPE 1991, The Psychology of Attitude Change and Social Influence, Boston: McGraw Hill. 


\section{IZA Discussion Papers}

\begin{tabular}{|c|c|c|c|c|}
\hline No. & Author(s) & Title & Area & Date \\
\hline 635 & $\begin{array}{l}\text { M. Karanassou } \\
\text { J. D. Snower }\end{array}$ & An Anatomy of the Phillips Curve & 3 & $11 / 02$ \\
\hline 636 & $\begin{array}{l}\text { M. Karanassou } \\
\text { H. Sala } \\
\text { J. D. Snower }\end{array}$ & $\begin{array}{l}\text { A Reappraisal of the Inflation-Unemployment } \\
\text { Tradeoff }\end{array}$ & 3 & $11 / 02$ \\
\hline 637 & $\begin{array}{l}\text { H. Bonin } \\
\text { W. Kempe } \\
\text { H. Schneider }\end{array}$ & $\begin{array}{l}\text { Household Labor Supply Effects of Low-Wage } \\
\text { Subsidies in Germany }\end{array}$ & 3 & $11 / 02$ \\
\hline 638 & $\begin{array}{l}\text { L. McLeod } \\
\text { M. R. Veall }\end{array}$ & $\begin{array}{l}\text { The Dynamics of Food Deprivation and Overall } \\
\text { Health: Evidence from the Canadian National } \\
\text { Population Health Survey }\end{array}$ & 2 & $11 / 02$ \\
\hline 639 & G. Saint-Paul & Are Intellectual Property Rights Unfair? & 3 & $11 / 02$ \\
\hline 640 & $\begin{array}{l}\text { J. Hartog } \\
\text { N. Jonker } \\
\text { H. van Ophem }\end{array}$ & $\begin{array}{l}\text { Dual Track or Academic Route for Auditors: } \\
\text { Does It Matter? }\end{array}$ & 6 & $11 / 02$ \\
\hline 641 & $\begin{array}{l}\text { J. Hartog } \\
\text { L. Diaz Serrano }\end{array}$ & $\begin{array}{l}\text { Earning Risk and Demand for Higher Education: } \\
\text { A Cross-Section Test for Spain }\end{array}$ & 2 & $11 / 02$ \\
\hline 642 & $\begin{array}{l}\text { J. Hartog } \\
\text { A. Zorlu }\end{array}$ & $\begin{array}{l}\text { The Effect of Immigration on Wages in Three } \\
\text { European Countries }\end{array}$ & 1 & $11 / 02$ \\
\hline 643 & $\begin{array}{l}\text { A. Björklund } \\
\text { M. Sundström }\end{array}$ & $\begin{array}{l}\text { Parental Separation and Children's Educational } \\
\text { Attainment: A Siblings Approach }\end{array}$ & 6 & $11 / 02$ \\
\hline 644 & $\begin{array}{l}\text { J. D. Brown } \\
\text { J. S. Earle }\end{array}$ & $\begin{array}{l}\text { Job Reallocation and Productivity Growth Under } \\
\text { Alternative Economic Systems and Policies: } \\
\text { Evidence from the Soviet Transition }\end{array}$ & 4 & $11 / 02$ \\
\hline 645 & $\begin{array}{l}\text { M. Karanassou } \\
\text { H. Sala } \\
\text { D. J. Snower }\end{array}$ & $\begin{array}{l}\text { Long-Run Inflation-Unemployment Dynamics: } \\
\text { The Spanish Phillips Curve and Economic Policy }\end{array}$ & 3 & $11 / 02$ \\
\hline 646 & $\begin{array}{l}\text { L. Graham } \\
\text { D. Snower }\end{array}$ & The Return of the Long-Run Phillips Curve & 3 & $11 / 02$ \\
\hline 647 & $\begin{array}{l}\text { C. Grund } \\
\text { D. Sliwka }\end{array}$ & Envy and Compassion in Tournaments & 1 & $11 / 02$ \\
\hline 648 & $\begin{array}{l}\text { C. Schnabel } \\
\text { T. Schank } \\
\text { J. Wagner }\end{array}$ & $\begin{array}{l}\text { Works Councils - Sand or Grease in the } \\
\text { Operation of German Firms? }\end{array}$ & 3 & $11 / 02$ \\
\hline 649 & $\begin{array}{l}\text { J. van Ours } \\
\text { J. Veenman }\end{array}$ & $\begin{array}{l}\text { From Parent to Child: Early Labor Market } \\
\text { Experiences of Second-Generation Immigrants } \\
\text { in the Netherlands }\end{array}$ & 1 & $11 / 02$ \\
\hline 650 & $\begin{array}{l}\text { H. Battu } \\
\text { P. J. Sloane }\end{array}$ & Overeducation and Ethnic Minorities in Britain & 2 & $11 / 02$ \\
\hline 651 & E. Schlicht & $\begin{array}{l}\text { Social Evolution, Corporate Culture, and } \\
\text { Exploitation }\end{array}$ & 3 & $11 / 02$ \\
\hline
\end{tabular}

An updated list of IZA Discussion Papers is available on the center's homepage www.iza.org. 